\title{
The first detection of Nosema ceranae (Microsporidia) in the small hive beetle, Aethina tumida Murray (Coleoptera: Nitidulidae)
}

\author{
Giovanni CiliA ${ }^{1}$, Ilaria CARDAIO ${ }^{1}$, Pedro Emanuel Jarmela dos SANTOS ${ }^{1}$, \\ James D. Ellis ${ }^{2}$, Antonio Nanetti ${ }^{1}$ \\ ${ }^{1}$ CREA-AA, Centro di Ricerca Agricoltura e Ambiente, Consiglio per la Ricerca in Agricoltura e l'Analisi dell'Economia \\ Agraria, Via di Saliceto 80, 40128, Bologna, Italy \\ ${ }^{2}$ Entomology and Nematology Department, University of Florida, Bldg. 970 Natural Area Dr., P.O. Box 110620, \\ Gainesville, FL 32607-0620, USA
}

Received 8 January 2018 - Revised 11 April 2018 - Accepted 20 July 2018

\begin{abstract}
In order to investigate the possible infection of Nosema ceranae in small hive beetle (SHB), Aethina tumida, in 2017, beetle specimens were sampled in Gainesville (Florida). By Real-Time PCR (qPCR), using previously developed primers based on the 16S rRNA gene, $N$. ceranae was detected in 7 out of $10 \mathrm{SHB}$ specimens, proving that the microsporidia can be transmitted by the alien beetle. This is the first report of $N$. ceranae infection in A. tumida, although evaluated on a few specimens.
\end{abstract}

\section{Nosema ceranae / small hive beetle / honey bee / qPCR / transmission / Aethina tumida}

\section{INTRODUCTION}

Nosemosis of western honey bees (Apis mellifera $)$ is an infection caused by microsporidians belonging to the Nosema genus. It occurs in individual bees and can impact overall colony health (Fries et al. 2013). For decades, nosemosis was attributed to Nosema apis (Zander 1909). More recently, two additional species were found to be associated with honey bees: Nosema ceranae (Fries et al. 1996) and Nosema neumanni (Chemurot et al. 2017), the latter being detected recently and only in Ugandan bees, with still unknown distribution and undescribed effects on A. mellifera .

$N$. ceranae was first identified infecting the ventricular epithelial cells of the Asian honey bee Apis cerana (Fries et al. 1996), a honey bee

Corresponding author: G. Cilia, giovanni.cilia@crea.gov.it

Manuscript editor: Peter Rosenkranz species generally accepted as the original host (Botías et al. 2012). However, the microsporidium was later found in A. mellifera colonies living in several areas of the world (Fries et al. 2006; Higes et al. 2006; Klee et al. 2007; Martin-Hernandez et al. 2007). Examination of preserved samples indicates that contact with $A$. mellifera must have occurred long before $N$. ceranae was recognised as a species (Chen et al. 2008; Ferroglio et al. 2013; Teixeira et al. 2013). The infections may be detrimental to the colonies and lead to their decline and collapse (Cox-Foster et al. 2007; Higes et al. 2008a), which makes $N$. ceranae a major threat to honey bees. Transmission occurs by incompletely elucidated routes; however, it is known that other Hymenoptera and insectivorous birds may be implicated in the dissemination of spores in the environment (Plischuk et al. 2009; Valera et al. 2011, 2017).

The small hive beetle (SHB), Aethina tumida (Murray 1867), is an invasive pest of A. mellifera . Native to Sub-Saharan Africa (Lundie 1940; 
Schmoke 1974), it has been detected in several countries worldwide since 1996 and presently, it is distributed on all continents except Antarctica (Al Toufailia et al. 2017; Lee et al. 2017; Neumann et al. 2016). It is widely distributed in North America and parts of Australia (Neumann et al. 2016), but has recently been found in Europe (da Silva 2014; Granato et al. 2017; Murilhas 2004; Palmeri et al. 2015). This species is an ecological generalist (Ellis and Hepburn 2006) that is capable of creating persistent populations with low density of honey bees (Arbogast et al. 2009).

Adult SHBs live in honey bee colonies, making them likely to encounter honey bee pathogens that they may be capable of spreading between bees or colonies (Eyer et al. 2009; Schäfer et al. 2010), thus increasing concerns related to SHB infestations. Herein, the aim of this investigation was the evaluation of Nosema spp. spores in SHB adults, possibly contributing to the transmission of nosemosis.

\section{MATERIALS AND METHODS}

\subsection{Sample collection}

One hive of European-derived honey bees with overt SHB infestation was selected in summer 2017 from an experimental apiary managed at the University of Florida, Gainesville, Florida, USA. No evident signs of nosemosis were present in the colony. A sample of $40 \mathrm{SHB}$ adults was randomly collected from combs and the hive floor and further split into two subsamples, one of 30 and one of 10 individuals.

\subsection{DNA extraction and $q P C R$ analysis}

Prior to analysis, the SHBs were washed with 95\% ethanol to remove any external Nosema spores that may have been present. Following this, the abdomens were dissected, crushed, and DNA extracted with a DNeasy Blood \& Tissue Kit (Qiagen S.p.a., Milan, Italy) following the manufacturer's instructions. The 30 abdomens of the first subsample were pooled and processed together to determine the average Nosema spp. abundance. The second subsample was used for individual SHB examinations and to estimate the proportion of positive individuals.
Multiplex Real-Time PCR (qPCR) was performed in duplicate from the same DNA extracts using primers and probes for $N$. apis and $N$. ceranae as reported by Fries et al. 2013.

The optimised amplification and quantitation protocol for Multiplex qPCR was as follows: $15 \mathrm{~min}$ at $98{ }^{\circ} \mathrm{C}$ followed by 40 cycles of denaturation for $5 \mathrm{~s}$ at $98^{\circ} \mathrm{C}$, annealing/extension for $10 \mathrm{~s}$ at $63{ }^{\circ} \mathrm{C}$, and melt curve analysis from 65 to $95^{\circ} \mathrm{C}$ (in $0.5^{\circ} \mathrm{C}$ increments) $10 \mathrm{~s} /$ step.

Light microscopy was used to evaluate the stage of Nosema spores in SHBs. Spore counting was estimated by haemocytometer as described by Fries et al. (2013).

\section{RESULTS}

The qPCR analysis performed on the pooled sample resulted in 15,646 N. ceranae copies being found (Table I), corresponding to an average of 521.5 copies per individual SHB. The number of copies found in the individual SHBs averaged 691.3 with an s.d. of 1.544.1 (Table I). However, $N$. ceranae was not found in three of those samples, which indicates a $70 \%$ prevalence of positive individuals. Considering all the analysed samples $(N=40)$, the average number of detected $N$. ceranae copies per adult SHB was 564.0. $N$. apis was not funded in any of the samples.

\section{DISCUSSION AND CONCLUSION}

Data show for the first time that SHB abdomens are associated with $N$. ceranae. This does not imply that SHBs are vectors or mechanical transmitters of the pathogen, but it does suggest either is possible. More work needs to be done to clarify this.

$N$. ceranae shows reproductive capability in different Hymenopteran hosts but there is no present evidence that it can multiply in Coleopteran species. In fact, it is possible that the SHBs in this investigation did not contain vegetative stages of $N$. ceranae but rather spores, as was observed under the light microscope. Histological investigations should be made to assess $N$. ceranae ability to complete its lifecycle in the SHB. This could revise the views of the transmission of nosemosis. 
Table I. Nosema ceranae copies detected by RT-PCR in small hive beetle abdomens and relevant $\mathrm{C} t$ data (asterisks denote the same $\mathrm{Ct}$ as the negative control)

\begin{tabular}{lcc}
\hline Sample & $\begin{array}{l}\text { Mean N. ceranae } \\
\text { copies } \pm \text { s.d. }\end{array}$ & $\begin{array}{l}\text { Mean Ct } \\
\pm \text { s.d. }\end{array}$ \\
\hline $\begin{array}{c}\text { Pooled sample } \\
(\text { 30 individuals })\end{array}$ & $15,646 \pm 6.82$ & $32 \pm 2$ \\
SHB 1 & $<$ LOD & $40^{*}$ \\
SHB 2 & $420 \pm 1.32$ & $34 \pm 6$ \\
SHB 3 & $969 \pm 2.13$ & $34 \pm 1$ \\
SHB 4 & $<$ LOD & $40^{*}$ \\
SHB 5 & $4.3 \pm 0.05$ & $36 \pm 4$ \\
SHB 6 & $<$ LOD & $40^{*}$ \\
SHB 7 & $120 \pm 3.58$ & $32 \pm 6$ \\
SBH 8 & $320 \pm 1.01$ & $34 \pm 2$ \\
SHB 9 & $5000 \pm 0.98$ & $35 \pm 2$ \\
SHB 10 & $80 \pm 1.09$ & $33 \pm 4$ \\
\hline
\end{tabular}

Several bee species may be infected by $N$. ceranae. These include some stingless bees (Meliponini) (Porrini et al. 2017), the solitary bees Osmia cornuta, Osmia bicornis, Heriades truncorum, and Andrena ventralis (Ravoet et al. 2014), and the bumblebee species Bombus brasiliensis (Plischuk and Lange 2016), Bombus atratus, Bombus morio, and Bombus bellicosus (Plischuk et al. 2009). The microsporidium also was detected in the social wasp Polybia scutellaris (Vespidae) (Porrini et al. 2017). Also, in regurgitated pellet of Merops apiaster, beeeater bird, vital $N$. ceranae spores was detected (Higes et al. 2008b). All of these species potentially share the same environment with A. mellifera and Aethina tumida .

Likewise, SHBs were detected in the nests of several bee species, nests in which they showed the ability to reproduce the bumblebee Bombus impatiens (Spiewok and Neumann 2006) and the stingless bees Austroplebeia australis (Halcroft et al. 2011), Dactylurina staudingeri (Mutsaers 2006), Melipona beecheii (Lóriga Peña et al. 2014), and Trigona carbonaria (Greco et al. 2010).

The knowledge about the effects of $N$. ceranae infections and SHB infestations on the host species above is limited. However, considering the low specificity of both pests and the high prevalence of Nosema positive SHBs in limited samples of this investigation, the possible role of SHB in the transmission of Nosema spp. within the members of the reared and wild community of pollinators should be considered further as a matter of ecological concern. The infection of Nosema ceranae in SHBs adults may confirm the transmission of pathology from original host to other species, like Deformed Wing Virus (DWV) replicative form funded in Vespa crabro (Forzan et al. 2017a; Forzan et al. 2017b)

The presence of spores in the SHB abdomens suggests that they may have been ingested by the beetles. This is compatible with the fact that SHB adults feed on colony stores (Buchholz et al. 2008; Neumann et al. 2016; Pirk and Neumann 2013) and with the description of bee-collected pollen as a possible $N$. ceranae spore reservoir (Higes et al. $2008 \mathrm{c}$ ). Another possible contamination route may be related to the SHB ability to interact with the workers to elicit a trophallactic food transfer via antennal stimulation (Ellis 2005; Ellis et al. 2002).

The average number of spores detected in the SHB abdomens is 6.6 times the median infective dose $\left(\mathrm{ID}_{50}=85\right.$ spores) for the honey bee (Forsgren and Fries 2010). This investigation does not elucidate the mode of transmission to the bees but, in case those spores are shared between a limited number of individuals and are fully viable, the possibility to generate SHB-mediated Nosema transmission becomes realistic.

The transmission routes of $N$. ceranae between bees and SHBs need further investigation. In bees, $N$. ceranae is transmitted via the oral-oral and faecal-oral route (Higes et al. 2009; Smith 2012). Both routes may be viable for the interaction between honey bees and SHBs given that the beetles are fed by honey bee workers. This could be a route of transmission in both directions. In addition, adult and larval SHBs defecate inside the hive with the larval faeces suspected of causing honey to ferment (Cuthbertson et al. 2013). This, too, could be a transmission route. The influence of different SHB life-history stages on $N$. ceranae infections should be studied to evaluate their potential epidemiological and ecological impact.

The no detection of $N$. apis may be a consequence of the climate where the samples were taken (warm/temperate with mild winters and 
hot summers), season (summer), or of the still controversial possible competition between the two Nosema species (Chen et al. 2012; Forsgren and Fries 2010; Martín-Hernández et al. 2012).

The detection of $N$. ceranae spores in the SHB abdomens at levels quantitatively sufficient to produce an outbreak suggests a possible role of Aethina tumida in nosemosis infection, though that careful investigation of this topic is needed to confirm this hypothesis. The low host specificity of SHB and its increasing spread may represent a further risk factor, ultimately jeopardising pollinator diversity. Further research efforts are needed to elucidate whether Aethina tumida adults act as a dead-end host, mechanical transmitter, or vector of $N$. ceranae.

\section{ACKNOWLEDGMENTS}

This study was conducted within the project AETHINET ("Monitoraggio e tecniche innovative di diagnosi e di controllo del piccolo coleottero dell'alveare, Aethina tumida") financed by the Italian Ministry of Agricultural, Food and Forestry Policies.

The authors are grateful to Brandi Simmons and Branden Stanford of the Entomology and Nematology Department, University of Florida, for their valuable technical support.

Contributions Conceived and designed the experiments: GC. Performed the experiments: IC, GC, and PJ. Analysed the data: IC. Wrote the original draft: AN, GC, PJ, IC, and JE. Review and editing: JE, AN, and GC. Supervision: AN and JE. All authors read and approved the final manuscript.

La première détection de Nosema ceranae (Microsporidia) dans le petit coléoptère des ruches, Aethina tumida Murray (Coleoptera: Nitidulidae)

Nosema ceranae / petit coléoptère de la ruche / abeille / qPCR / transmission / Aethina tumida

Erster Nachweis von Nosema ceranae (Microsporidia) in dem Kleinen Beutenkäfer, Aethina tumida Murray (Coleoptera: Nitidulidae)

Nosema ceranae / Kleiner Beutenkäfer / Honigbiene / qPCR / Transmission / Aethina tumida

\section{REFERENCES}

Al Toufailia, H., Alves, D.A., de Bená, D. C., Bento, J.M.S., Iwanicki, N.S.A., Cline, A.R., Ellis, J.D., Ratnieks, F.L.W., 2017. First record of small hive beetle, Aethina tumida Murray, in South America. J. Apic. Res. 56, 76-80. https://doi.org/10.1080 /00218839.2017.1284476

Arbogast, R.T., Torto, B., Willms, S., Teal, P.E.A., 2009. Trophic habits of Aethina tumida (Coleoptera: Nitidulidae): their adaptive significance and relevance to dispersal. Environ. Entomol. 38, 561-568. https://doi.org/10.1603/022.038.0307

Botías, C., Anderson, D.L., Meana, A., Garrido-Bailón, E., Martín-Hernández, R., Higes, M., 2012. Further evidence of an oriental origin for Nosema ceranae (Microsporidia: Nosematidae). J. Invertebr. Pathol. 110, 108-113. https://doi.org/10.1016/J.JIP.2012.02.014

Buchholz, S., Schäfer, M.O., Spiewok, S., Pettis, J.S., Duncan, M., Ritter, W., Spooner-Hart, R., Neumann, P., 2008. Alternative food sources of Aethina tumida (Coleoptera: Nitidulidae). J. Apic. Res. 47, 202-209. https://doi.org/10.1080/00218839.2008.11101460

Chemurot, M., De Smet, L., Brunain, M., De Rycke, R., de Graaf, D.C., 2017. Nosema neumanni n. sp. (Microsporidia, Nosematidae), a new microsporidian parasite of honeybees, Apis mellifera in Uganda. Eur. J. Protistol. 61, 13-19. https://doi.org/10.1016/J. EJOP.2017.07.002

Chen, Y., Evans, J.D., Smith, I.B., Pettis, J.S., 2008. Nosema ceranae is a long-present and wide-spread microsporidian infection of the European honey bee (Apis mellifera) in the United States. J. Invertebr. Pathol. 97, 186-188. https://doi.org/10.1016/j. jip.2007.07.010

Chen, Y.W., Chung, W.P., Wang, C.H., Solter, L.F., Huang, W.F., 2012. Nosema ceranae infection intensity highly correlates with temperature. J. Invertebr. Pathol. 111, 264-267. https://doi.org/10.1016/j.jip.2012.08.014

Cox-Foster, D.L., Conlan, S., Holmes, E.C., Palacios, G., Evans, J.D., Moran, N.A., Quan, P.-L., Briese, T., Hornig, M., Geiser, D.M., Martinson, V., VanEngelsdorp, D., Kalkstein, A.L., Drysdale, A., Hui, J., Zhai, J., Cui, L., Hutchison, S.K., Simons, J.F., Egholm, M., Pettis, J.S., Lipkin, W.I., 2007. A Metagenomic Survey of Microbes in Honey Bee Colony Collapse Disorder. Science (80-. ). 318, 283-287.

Cuthbertson, A.G.S., Wakefield, M.E., Powell, M.E., Marris, G., Anderson, H., Budge, G.E., Mathers, J.J., Blackburn, L.F., Brown, M.A., 2013. The small hive beetle Aethina tumida : A review of its biology and control measures. Curr. Zool. 59, 644-653. https://doi. org/10.1093/czoolo/59.5.644

da Silva, M.J.V., 2014. The First Report Of Aethina tumida In The European Union, Portugal, 2004. Bee World 91, 90-91. https://doi.org/10.1080/0005772 X.2014.11417619

Ellis, J.D., 2005. Reviewing the confinement of small hive beetles (Aethina tumida) by western honey bees (Apis 
mellifera ). Bee World 86, 56-62. https://doi. org/10.1080/0005772X.2005.11417312

Ellis, J.D., Hepburn, H.R., 2006. An ecological digest of the small hive beetle (Aethina tumida), a symbiont in honey bee colonies (Apis mellifera). Insect. Soc. 53, 819. https://doi.org/10.1007/s00040-005-0851-8

Ellis, J.D., Pirk, C.W.W., Hepburn, H.R., Kastberger, G., Elzen, P.J., 2002. Small hive beetles survive in honeybee prisons by behavioural mimicry. Naturwissenschaften 89, 326-328. https://doi. org/10.1007/s00114-002-0326-y

Eyer, M., Chen, Y.P., Schäfer, M.O., Pettis, J., Neumann, P., 2009. Small hive beetle, Aethina tumida , as a potential biological vector of honeybee viruses. Apidologie 40, 419-428. https://doi.org/10.1051/apido:2008051

Ferroglio, E., Zanet, S., Peraldo, N., Tachis, E., Trisciuoglio, A., Laurino, D., Porporato, M., 2013. Nosema ceranae has been infecting honey bees Apis mellifera in Italy since at least 1993. J. Apic. Res. 52, 60-61. https://doi.org/10.3896/IBRA.1.52.2.11

Forsgren, E., Fries, I., 2010. Comparative virulence of Nosema ceranae and Nosema apis in individual European honey bees. Vet. Parasitol. 170, 212-217. https://doi.org/10.1016/j.vetpar.2010.02.010

Forzan, M., Felicioli, A., Sagona, S., Bandecchi, P., Mazzei, M., 2017a. Complete Genome Sequence of Deformed Wing Virus Isolated from Vespa crabro in Italy. Genome Announc. 5. https://doi.org/10.1128/genomeA.00961-17

Forzan, M., Sagona, S., Mazzei, M., Felicioli, A., 2017 b. Detection of deformed wing virus in Vespa crabro. Bull. Insectology 70, 261-265.

Fries, I., Feng, F., da Silva, A., Slemenda, S.B., Pieniazek, N.J., 1996. Nosema ceranae n. sp. (Microspora, Nosematidae), morphological and molecular characterization of a microsporidian parasite of the Asian honey bee Apis cerana (Hymenoptera, Apidae). Eur. J. Protistol. 32, 356-365. https://doi.org/10.1016/S0932-4739(96)80059-9

Fries, I., Martín, R., Meana, A., García-Palencia, P., Higes, M., 2006. Natural infections of Nosema ceranae in European honey bees. J. Apic. Res. 45, 230-233. https://doi.org/10.1080/00218839.2006.11101355

Fries, I., Chauzat, M.-P., Chen, Y.-P., Doublet, V., Genersch, E., Gisder, S., Higes, M., McMahon, D.P., Martín-Hernández, R., Natsopoulou, M., Paxton, R.J., Tanner, G., Webster, T.C., Williams, G.R., 2013. Standard methods for Nosema research. J. Apic. Res. 52, 1-28. https://doi. org/10.3896/IBRA.1.52.1.14

Granato, A., Zecchin, B., Baratto, C., Duquesne, V., Negrisolo, E., Chauzat, M.-P., Ribière-Chabert, M., Cattoli, G., Mutinelli, F., 2017. Introduction of Aethina tumida (Coleoptera: Nitidulidae) in the regions of Calabria and Sicily (southern Ita1y). Apidologie 48, 194-203. https://doi. org/10.1007/s13592-016-0465-3

Greco, M.K., Hoffmann, D., Dollin, A., Duncan, M., Spooner-Hart, R., Neumann, P., 2010. The alternative Pharaoh approach: Stingless bees mummify beetle parasites alive. Naturwissenschaften 97, 319-323. https://doi.org/10.1007/s00114-009-0631-9

Halcroft, M., Spooner-Hart, R., Neumann, P., 2011. Behavioral defense strategies of the stingless bee, Austroplebeia australis, against the small hive beetle, Aethina tumida . Insect. Soc.. 58, 245-253. https://doi. org/10.1007/s00040-010-0142-x

Higes, M., Martín, R., Meana, A., 2006. Nosema ceranae, a new microsporidian parasite in honeybees in Europe. $\mathrm{J}$. Invertebr. Pathol. 92, 93-95. https://doi.org/10.1016/j. jip.2006.02.005

Higes, M., Martín-Hernández, R., Botías, C., Bailón, E.G., González-Porto, A. V., Barrios, L., Del Nozal, M.J., Bernal, J.L., Jiménez, J.J., Palencia, P.G., Meana, A., 2008a. How natural infection by Nosema ceranae causes honeybee colony collapse. Environ. Microbiol. 10, 2659-2669. https://doi.org/10.1111/j.14622920.2008.01687.x

Higes, M., Martín-Hernández, R., Garrido-Bailón, E., Botías, C., García-Palencia, P., Meana, A., 2008b. Regurgitated pellets of Merops apiaster as fomites of infective Nosema ceranae (Microsporidia) spores. Environ. Microbiol. 10, 1374-1379. https://doi. org/10.1111/j.1462-2920.2007.01548.x

Higes, M., Martín-Hernández, R., Garrido-Bailón, E., García-Palencia, P., Meana, A., 2008c. Detection of infective Nosema ceranae (Microsporidia) spores in corbicular pollen of forager honeybees. J. Invertebr. Pathol. 97, 76-78. https://doi.org/10.1016/j. jip.2007.06.002

Higes, M., Martin-Hernandez, R., Garci-a-Palencia, P., Mari-n, P., Meana, A., 2009. Horizontal transmission of Nosema ceranae (Microsporidia) from worker honeybees to queens (Apis mellifera ). Environ. Microbiol. Rep. 1, 495-498. https://doi. org/10.1111/j.1758-2229.2009.00052.x

Klee, J., Besana, A.M., Genersch, E., Gisder, S., Nanetti, A., Tam, D.Q., Chinh, T.X., Puerta, F., Ruz, J.M., Kryger, P., Message, D., Hatjina, F., Korpela, S., Fries, I., Paxton, R.J., 2007. Widespread dispersal of the microsporidian Nosema ceranae, an emergent pathogen of the western honey bee, Apis mellifera. J. Invertebr. Pathol. 96, 1-10. https://doi.org/10.1016/j. jip.2007.02.014

Lee, S., Hong, K.-J., Cho, Y.S., Choi, Y.S., Yoo, M.-S., Lee, S., 2017. Review of the subgenus Aethina Erichson s. str. (Coleoptera: Nitidulidae: Nitidulinae) in Korea, reporting recent invasion of small hive beetle, Aethina tumida. J. Asia Pac. Entomol. 20, 553-558. https://doi. org/10.1016/J.ASPEN.2017.03.006

Lóriga Peña, W., Fonte Carballo, L., Demedio Lorenzo, J., (2014) Revista de salud animal., Revista de Salud Animal. Centro Nacional de Salud Animal.

Lundie, A.E., 1940. The Small Hive Beetle, Aethina túmida. Sci. Bull. 220, 40.

Martin-Hernandez, R., Meana, A., Prieto, L., Salvador, A.M., Garrido-Bailon, E., Higes, M., 2007. Outcome of Colonization of Apis mellifera by Nosema ceranae. Appl. Environ. Microbiol. 73, 6331-6338. https://doi. org/10.1128/AEM.00270-07 
Martín-Hernández, R., Botías, C., Bailón, E.G., MartínezSalvador, A., Prieto, L., Meana, A., Higes, M., 2012. Microsporidia infecting Apis mellifera: Coexistence or competition. Is Nosema ceranae replacing Nosema apis? Environ. Microbiol. 14, 2127-2138. https://doi. org/10.1111/j.1462-2920.2011.02645.x

Murilhas, A.M., 2004. Aethina tumida arrives in Portugal. Will it be eradicated? EurBee Newsletters 2, 7-9.

Murray, A., 1867. List of Coleoptera received from Old Calabar. Ann. Mag. Nat. Hist. London 19, 167-179.

Mutsaers, M., 2006. Beekeepers' observations on the small hive beetle (Aethina tumida) and other pests in bee colonies in West and East Africa, in: Vesely, V., Titera, D. (Eds.), Proceedings of the Second European Conference of Apidology. Bee Research Institute Dol, CZ, Prague, Czech Republic, p. 44.

Neumann, P., Pettis, J.S., Schäfer, M.O., 2016. Quo vadis Aethina tumida? Biology and control of small hive beetles. Apidologie 47, 427-466. https://doi. org/10.1007/s13592-016-0426-x

Palmeri, V., Scirtò, G., Malacrinò, A., Laudani, F., Campolo, O., 2015. A scientific note on a new pest for European honeybees: first report of small hive beetle Aethina tumida, (Coleoptera: Nitidulidae) in Italy. Apidologie 46, 527-529. https://doi. org/10.1007/s13592-014-0343-9

Pirk, C.W.W., Neumann, P., 2013. Small Hive Beetles are Facultative Predators of Adult Honey Bees. J. Insect Behav. 26, 796-803. https://doi.org/10.1007/s10905013-9392-6

Plischuk, S., Lange, C.E., 2016. Bombus brasiliensis Lepeletier (Hymenoptera, Apidae) infected with Nosema ceranae (Microsporidia). Rev. Bras. Entomol. 60,347-351. https://doi.org/10.1016/J. RBE.2016.06.003

Plischuk, S., Martín-Hernández, R., Prieto, L., Lucía, M., Botías, C., Meana, A., Abrahamovich, A.H., Lange, C., Higes, M., 2009. South American native bumblebees (Hymenoptera: Apidae) infected by Nosema ceranae ( Microsporidia), an emerging pathogen of honeybees (Apis mellifera ). Environ. Microbiol. Rep. 1, 131-135. https://doi.org/10.1111/j.17582229.2009.00018.x

Porrini, M.P., Porrini, L.P., Garrido, P.M., de Melo e Silva Neto, C., Porrini, D.P., Muller, F., Nuñez, L.A.,
Alvarez, L., Iriarte, P.F., Eguaras, M.J., 2017. Nosema ceranae in South American Native Stingless Bees and Social Wasp. Microb. Ecol. 74, 761-764. https://doi. org/10.1007/s00248-017-0975-1

Ravoet, J., De Smet, L., Meeus, I., Smagghe, G., Wenseleers, T., De Graaf, D.C., 2014. Widespread occurrence of honey bee pathogens in solitary bees. J. Invertebr. Pathol. 122, 55-58. https://doi.org/10.1016 j.jip.2014.08.007

Schäfer, M.O., Ritter, W., Pettis, J., Neumann, P., 2010. Small hive beetles, Aethina tumida, are vectors of Paenibacillus larvae. Apidologie 41, 14-20. https://doi.org/10.1051/apido/2009037

Schmoke, M.D. (1974) A study of Aethina tumida: the small hive beetle, Project Report, University of Rhodesia, Zimbabwe

Smith, M.L., 2012. The Honey Bee Parasite Nosema ceranae: Transmissible via Food Exchange? PLoS One 7, e43319. https://doi.org/10.1371/journal. pone. 0043319

Spiewok, S., Neumann, P., 2006. Infestation of commercial bumblebee (Bombus impatiens) field colonies by small hive beetles (Aethina tumida). Ecol. Entomol. 31, 623628. https://doi.org/10.1111/j.1365-2311.2006.00827. $\mathrm{X}$

Teixeira, E.W., dos Santos, L.G., Sattler, A., Message, D., Alves, M.L.T.M.F., Martins, M.F., Grassi-Sella, M.L., Francoy, T.M., 2013. Nosema ceranae has been present in Brazil for more than three decades infecting Africanized honey bees. J. Invertebr. Pathol. 114, 250-254. https://doi.org/10.1016/j.jip.2013.09.002

Valera, F., Martín-Hernández, R., Higes, M., 2011. Evaluation of large-scale dissemination of Nosema ceranae spores by European bee-eaters Merops apiaster. Environ. Microbiol. Rep. 3, 47-53. https://doi.org/10.1111 /j.1758-2229.2010.00186.x

Valera, F., Gómez-Moracho, T., Yuan, H.-W., Muñoz, I., De la Rúa, P., Martín-Hernández, R., Chen, Y.-L., Higes, M., 2017. Any role for the dissemination of Nosema spores by the blue-tailed bee-eater Merops philippinus ? J. Apic. Res. 56, 262-269. https://doi.org/10.1080 /00218839.2017.1306375

Zander, E., 1909. Tierische Parasiten als Krankenheitserreger beider Biene. Münch Bienenztg 31, 196-2014. 